\title{
Spatial analysis of sap consumption by birds in the Chaco dry forests from Argentina
}

\author{
Leandro Macchi $^{\mathrm{A}, \mathrm{B}}$, Pedro G. Blendinger ${ }^{\mathrm{A}}$ and M. Gabriela Núñez Montellano ${ }^{\mathrm{A}}$ \\ A Instituto de Ecología Regional and Consejo Nacional de Investigaciones Científicas y Técnicas (CONICET), \\ Universidad Nacional de Tucumán, CC 34, 4107 Yerba Buena, Tucumán, Argentina. \\ ${ }^{B}$ Corresponding author. Email: leandrom_84@hotmail.com
}

\begin{abstract}
Sap is a resource of high energy content that is usually inaccessible to birds, although woodpeckers have the ability to drill into living trees to obtain sap. Because spatial patterns of resource availability influence avian abundance, we explored how spatial patterns of sap availability determine the spatial distribution of two sap-feeding species in the semiarid Chaco of Argentina. We studied the White-fronted Woodpecker (Melanerpes cactorum), which obtains sap by drilling holes into tree trunks, and the Glittering-bellied Emerald (Chlorostilbon aureoventris), which can obtain sap only from active woodpecker holes; 12 other bird species also exploited the sap flows from holes drilled by White-fronted Woodpeckers. The abundance of tree species used for sap feeding did not explain the spatial patterns of territorial groups of White-fronted Woodpeckers. However, within each territory, the abundance of Woodpeckers was centred on a single tree from which sap was obtained. The abundance of the Emeralds was strongly associated with the availability of trees with active sap-holes. During the dry season, sap is a major component in the diet of White-fronted Woodpeckers and Glittering-bellied Emeralds. However, the spatial distribution of these two consumers in relation to the availability of sap was species-specific. This species-specific response was closely related to the ecology and life history of each species. The abundance of woodpeckers could be determined by local mechanisms, such as location of a single sap tree in their small territories, whereas non-territorial hummingbirds would be able to track sap wells at a larger scale than the territory of a single territorial group of Woodpeckers. Our results show the importance of spatial analysis in identifying the ecological determinant of habitat selection and niche differentiation within species.
\end{abstract}

Additional keywords: Chlorostilbon aureoventris, facilitation, foraging behaviour, Glittering-bellied Emerald, hummingbirds, Melanerpes cactorum, resource tracking, White-fronted Woodpecker.

\section{Introduction}

Among American woodpeckers, a number of species are known to drill holes in living trees to consume phloem sap, including species of Melanerpes (Genise et al. 1993), Sphyrapicus (Tate 1973), Picoides (Kozma 2010) and Campephilus (Schlatter and Vergara 2005). Sap-consuming woodpeckers select among and within tree species (Kattan 1988; Blendinger 1999; Eberhardt 2000) so the availability of sap trees might be a determining factor in the spatial distribution of these species of woodpecker. Similarly, the spatial distribution of sap trees and the sap holes created by woodpeckers might also determine the spatial patterns and abundance of other sap-feeding species that exploit woodpeckers' sap holes. Because sap and nectar provide similar food resources, nectarivorous birds are particularly likely to feed on sap from sap holes created by woodpeckers. Hummingbirds in North America include high volumes of sap in their diets (Miller and Nero 1983), for example sap in holes drilled by the Yellow-bellied Sapsucker (Sphyrapicus varius) can be the main resource for the Ruby-throated Hummingbird (Archilochus colubris) especially during the nesting season when the hummingbirds rarely take flower nectar (Southwick and Southwick 1980).
Some honeyeater species (Meliphagidae) in Australia also regularly use sap flows, though the extent of such sap foraging is not well known and apparently under-reported (Chapman et al. 1999).

Our study focussed on the responses of sap-feeding species to spatial patterns of sap availability in the Chaco dry forests of South America. There the White-fronted Woodpecker (Melanerpes cactorum) drills holes in branches and trunks of trees to feed on sap flows (Genise et al. 1993), providing an energy-rich food resource for other birds to exploit during the cold dry season, when insects, fruits and flowers are scarce (Codesido and Bilenca 2004). At least 15 species of birds are known to eat sap from active holes drilled by woodpeckers in the dry woodlands of southern South America (Genise et al. 1993; Blendinger 1999). The ability of birds to track the spatial variability of food availability depends on factors such as the scale at which each consumer species perceives resources and the relative importance of the resource in the diet (Nekola and White 1999; Shochat et al. 2002; Seppänen et al. 2007). Spatial structure is an important component of natural systems that needs to be included in the analysis of ecological processes (Wagner and Fortin 2005; García 
et al. 2009). A spatially explicit analysis of the resourceconsumer relationship may contribute valuable information on the gradient of scales at which these factors operate and on the spatial structure of ecological responses by species to spatial resource heterogeneity (Fortin and Dale 2005; Wagner and Fortin 2005).

The first aim of this study was to evaluate if the spatial distribution of tree species used for sap consumption determined the pattern of use of territories by White-fronted Woodpeckers and to explore the spatial scale at which individuals responded to the resource. If sap resource availability determines the distribution of Woodpeckers, we expected a spatial relationship between the abundance of Woodpeckers and the abundance of trees used for sap extraction. The second aim of the work was to evaluate if active holes drilled by White-fronted Woodpeckers determined the use of space by the Glittering-bellied Emerald (Chlorostilbon aureoventris), the most abundant hummingbird species in the Chaco dry forest. If hummingbirds track sap holes, we expect that the spatial patterns of abundance of this consumer should be structured in response to the distribution of Whitefronted Woodpeckers.

\section{Methods}

Study area and study species

We conducted the study in Rivadavia Banda Sur $\left(24^{\circ} 11^{\prime} \mathrm{S}\right.$, $62^{\circ} 53^{\prime} \mathrm{W}$ ), Salta Province, in north-western Argentina. The climate is seasonal monsoonal, with dry winters and rainy summers and an average annual of $650 \mathrm{~mm}$. The dry season normally extends from May to October. The area is located in the semiarid Chaco, in the Chaco phytogeographic province (Morello and Adámoli 1968; Cabrera and Willink 1980), characterised by semi-deciduous xerophilous forest. The White-fronted Woodpecker forms resident groups throughout the year (M. G. Núñez Montellano, P. G. Blendinger and L. Macchi, unpubl. data). They spend most of the day near trees with active sap holes (M. G. Núñez Montellano et al., unpubl. data) and show strong territorial behaviour and aggressive interactions, mainly with conspecifics as well as other species that approached the sap holes (Blendinger 1999). Our previous field observations suggested that forest structure and abundance of birds differed with distance from water in the semiarid Chaco. Thus, to select the study site we explored, at the landscape scale, the differences in abundance of sap consumers between areas located near and far from ponds. In 10 different ponds spaced $500 \mathrm{~m}$ or more apart, we established a pair of transects, each $200 \mathrm{~m}$ long and $700 \mathrm{~m}$ apart. The abundance of sap-feeding birds was four times greater near ponds than in forests far from waterbodies (Wilcoxon matchedpairs test, $Z=2.66, n=10, P<0.01$ ); thus, sampling was conducted in a site adjacent to a small permanent pond.

\section{Sampling of birds and trees}

The size of our study plot was large enough to include several territorial groups of White-fronted Woodpeckers and the structural heterogeneity representative of forests located near ponds. We established a $450 \times 300-\mathrm{m}$ plot along the edge of the pond $(450 \mathrm{~m})$ and extending into the forest $(300 \mathrm{~m})$, split into a grid of 108 cells $50 \times 25 \mathrm{~m}$. We were interested in the spatial distribution of the activity of sap-feeding birds. In each cell we quantified the relative abundance of White-fronted Woodpeckers and Glittering-bellied Emeralds, as a spatially explicit measure of the use of forest sites by these species, and determined the abundance of trees used for sap consumption.

To measure avian activity, three observers surveyed birds on three dates in June 2007. On each date, each observer surveyed one transect, comprising a block of 12 cells block perpendicular to the pond; we sampled each cell for $10 \mathrm{~min}$, for a total of $30 \mathrm{~min}$ per cell and $2 \mathrm{~h}$ per transect. Each block of 12 cells was covered at three different times and on alternate days to ensure uniform sampling effort among cells. We recorded the exact location of all individuals seen or heard within each cell, whether they were eating sap or other food, and the plant species used. For each cell we estimated the abundance of all adult plants of the species from which sap was obtained. We counted every tree $>10 \mathrm{~cm}$ diameter at breast height and all shrubs $>1 \mathrm{~m}$ tall. To determine the number of groups and the area of their territories, Woodpeckers were mist-netted and colour-marked. Individual birds and groups were observed throughout the study site and their position was recorded with a geographical positioning system (GPS; Garmin eTrex Legend).

In addition to the transect surveys, we spent total of $31 \mathrm{~h}$ following individual Woodpeckers in the plot, recording the amount of time they spent in trees with active sap holes.

\section{Statistical analyses}

We first explored the spatial relationship between the abundance of tree species from which sap obtained and the abundance of White-fronted Woodpeckers. We selected the consumerresource relationships that were significant at $P<0.05$ using a simple regression analysis, and we used these relationships in spatial models.

We explored the pattern of White-fronted Woodpecker (consumer) abundance and its covariance with resources (abundance of tree species from which sap obtained) at different scales using spatially explicit analyses. We used Moran's I correlograms (Legendre and Legendre 1998) to explore spatial autocorrelation among consumers, with distance classes of variable length but with similar number of compared point pairs and with a significance level of $P<0.05$. We used correlograms to evaluate autocorrelation intensity, size of the area of influence, and type of spatial pattern of the study variable. For the first objective, we used principal coordinates of neighbour matrices (PCNM) to generate spatially explicit models that decompose spatial variation of the response variable (abundance of Whitefronted Woodpeckers) and relate it to predictor variables (abundance of trees used for sap consumption). First, a series of vectors of principal coordinates is generated from an ordination analysis (principal coordinate analysis). These vectors represent all the periodical spatial structures that can be established from a spatially explicit group of sampling points (Borcard and Legendre 2002). We then used multiple regression analysis to contrast all the spatial vectors with the response variable (abundance of White-fronted Woodpeckers). Multiple regression analysis selects spatial templates (vectors) that can explain spatial variation in the response variable (those vectors with a partial regression coefficient significant at $P<0.05$ ). It also provides the percentage of spatial variance accounted for by these templates 
and generates expected values of the response variables. We explored the association between these expected values of consumer abundance and values of sap abundance by simple regressions (Borcard et al. 2004; García et al. 2009). We also used spatial analysis by distance indices (SADIE) (Perry and Dixon 2002), to explore the spatial association between the abundance of White-fronted Woodpeckers and that of trees used for sap consumption during the study period (with values 1 and 0 per $50 \times 50$-m sample unit). SADIE assesses local spatial association using the index $X$, which represents the correlation coefficient between the clustering indices of the two populations sampled. The significance of $X$ was tested with a randomisation test after adjustment for spatial autocorrelation.

For the second objective, we evaluated the spatial relationship between the abundance of Glittering-bellied Emeralds and White-fronted Woodpeckers. We consider the spatial abundance of Woodpeckers to be a good indicator of the distribution of sap available to the hummingbirds, given that the hummingbirds could only consume sap from trees used by the Woodpeckers, and because the Woodpeckers ate sap from only a few individual trees, in which they spent $>75 \%$ of their time. We applied the PCNM analysis using the abundance of Glittering-bellied Emeralds as the response variable and the abundance of White-fronted Woodpeckers as the predictor variable. We performed spatial analyses with the software SAM v2.0 (Rangel et al. 2006).

\section{Results}

Five family groups of Woodpeckers, a total of 28 individuals $(n=5,5,5,9$ and 4 individuals, mean \pm s.d. $=5.6 \pm 1.95)$, held territories wholly or partly in the 13.5-ha study plot. Mean size of territories was $1.39 \pm 0.17$ ha and included at least one individual of Stetsonia coryne, a columnar cactus in which Woodpeckers drill holes that are used as roosting sites by the entire family group. Each group mainly used one tree from which to obtain sap, although more than one tree per territory was used per group (M. G. Núñez Montellano et al., unpubl. data). We recorded a total of 13 bird species consuming sap at holes excavated by the Woodpeckers, the most frequent being Glittering-bellied Emeralds, Monk Parakeets (Miopsitta monachus), Greater WagtailTyrants (Stigmatura budytoides), and Black-capped WarblingFinch (Poospiza melanoleuca) (Table 1). The abundance of four species that fed on sap was correlated with the abundance of White-fronted Woodpeckers (Table 1). However, only the Glittering-bellied Emerald was abundant enough to allow a reliable spatial test.

\section{Sap consumption by White-fronted Woodpeckers}

Woodpeckers obtained sap from seven species of tree (Table 2), but mainly from Prosopis ruscifolia (87\% of records). Of all the species from sap was obtained, $P$. ruscifolia was the only one whose abundance was significantly and positively associated with the abundance of White-fronted Woodpeckers (simple regression, $R^{2}=0.05, n=108, P=0.022$ ) (Table 2).

The abundance of White-fronted Woodpeckers showed a significant positive autocorrelation among very close sites (mean distance of $54.3 \mathrm{~m}$ ) and among those at a mean intermediate distance of $151.5 \mathrm{~m}$ (Fig. 1a), showing aggregated patterns that correspond to territories and the spacing among them respectively. Abundance of $P$. ruscifolia did not show significant autocorrelation for any of the distance classes. PCNM generated 52 spatial vectors for the 108-cell grid. Four of the vectors were significantly associated with abundance of White-fronted Woodpeckers; these vectors represent the structure of the spatial variation in the abundance of Woodpeckers. Overall, all spatial vectors accounted for $21 \%$ of variability in the abundance of White-fronted Woodpeckers (multiple regression, $R^{2}=0.22$, $P<0.001$ ). Expected spatial values of Woodpecker abundance were not correlated with the abundance of $P$. ruscifolia $\left(R^{2}=0.10, P=0.36\right)$. However, the abundance of Woodpeckers was spatially associated with the location of trees from which sap was obtained (spatial association index $X=0.42, P=0.005$ ).

Table 1. Records of sap-feeding by birds in the study area

$n$, relative abundance (numbers of each species recorded in transects); Foraging records, the total number of observations of foraging; Sap-feeding, the total number of individuals observed feeding on sap at holes drilled by White-fronted Woodpecker; $R$ and $P$ values for the regression analysis between the abundance of each species and the abundance of White-fronted Woodpeckers (only species with $n>5$ were analysed)

\begin{tabular}{|c|c|c|c|c|c|}
\hline & $n$ & $\begin{array}{l}\text { Foraging } \\
\text { records }\end{array}$ & $\begin{array}{l}\text { Individuals } \\
\text { feeding } \\
\text { on sap }\end{array}$ & $R$ & $P$ \\
\hline Greater Wagtail-Tyrant (Stigmatura budytoides) & 102 & 81 & 5 & 0.23 & 0.018 \\
\hline Masked Gnatcatcher (Polioptila dumicola) & 68 & 58 & 2 & 0.16 & 0.10 \\
\hline Glittering-bellied Emerald (Chlorostilbon aureoventris) & 62 & 54 & 46 & 0.68 & $<0.001$ \\
\hline House Wren (Troglodytes aedon) & 18 & 18 & 1 & 0.28 & 0.004 \\
\hline Black-capped Warbling-Finch (Poospiza melanoleuca) & 18 & 14 & 5 & 0.25 & 0.010 \\
\hline Monk Parakeet (Myiopsitta monachus) & 14 & 6 & 6 & 0.43 & $<0.001$ \\
\hline Blue-and-yellow Tanager (Thraupis bonariensis) & 8 & 5 & 1 & 0.18 & 0.07 \\
\hline White-tipped Plantcutter (Phytotoma rutila) & 4 & 2 & 2 & - & - \\
\hline Pearly-vented Tody-Tyrant (Hemitriccus margaritaceiventer) & 3 & 3 & 1 & - & - \\
\hline Cream-backed Woodpecker (Campephilus leucopogon) & 2 & 2 & 1 & - & - \\
\hline Epaulet Oriole (Icterus cayanensis) & 2 & 2 & 2 & - & - \\
\hline Red-crested Cardinal (Paroaria capitata) & 1 & 1 & 1 & - & - \\
\hline Many-coloured Chaco-Finch (Saltatricula multicolor) & 1 & 1 & 1 & & \\
\hline
\end{tabular}


Table 2. Number of sap consumption events and simple regression analysis of abundance of White-fronted Woodpeckers and abundance of tree species from which sap obtained

Species with which abundance of Woodpeckers significantly associated indicated in bold

\begin{tabular}{lrrl}
\hline & $n$ & \multicolumn{1}{c}{$R^{2}$} & \multicolumn{1}{c}{$P$} \\
\hline Aspidosperma quebracho-blanco (Apocynaceae) & 2 & 0.03 & 0.08 \\
Bulnesia sarmientoi (Zygophyllaceae) & 5 & $<0.01$ & 0.62 \\
Ruprechtia apetala (Polygoneacea) & 6 & $<0.01$ & 0.70 \\
Prosopis ruscifolia (Fabaceae) & 104 & $\mathbf{0 . 0 5}$ & $\mathbf{0 . 0 2 2}$ \\
Ruprechtia triflora (Polygonaceae) & 2 & $<0.01$ & 0.43 \\
Schinus sp. (Anacardiaceae) & 2 & $<0.01$ & 0.70 \\
Ziziphus mistol (Rhamnaceae) & 2 & $<0.01$ & 0.87 \\
\hline
\end{tabular}
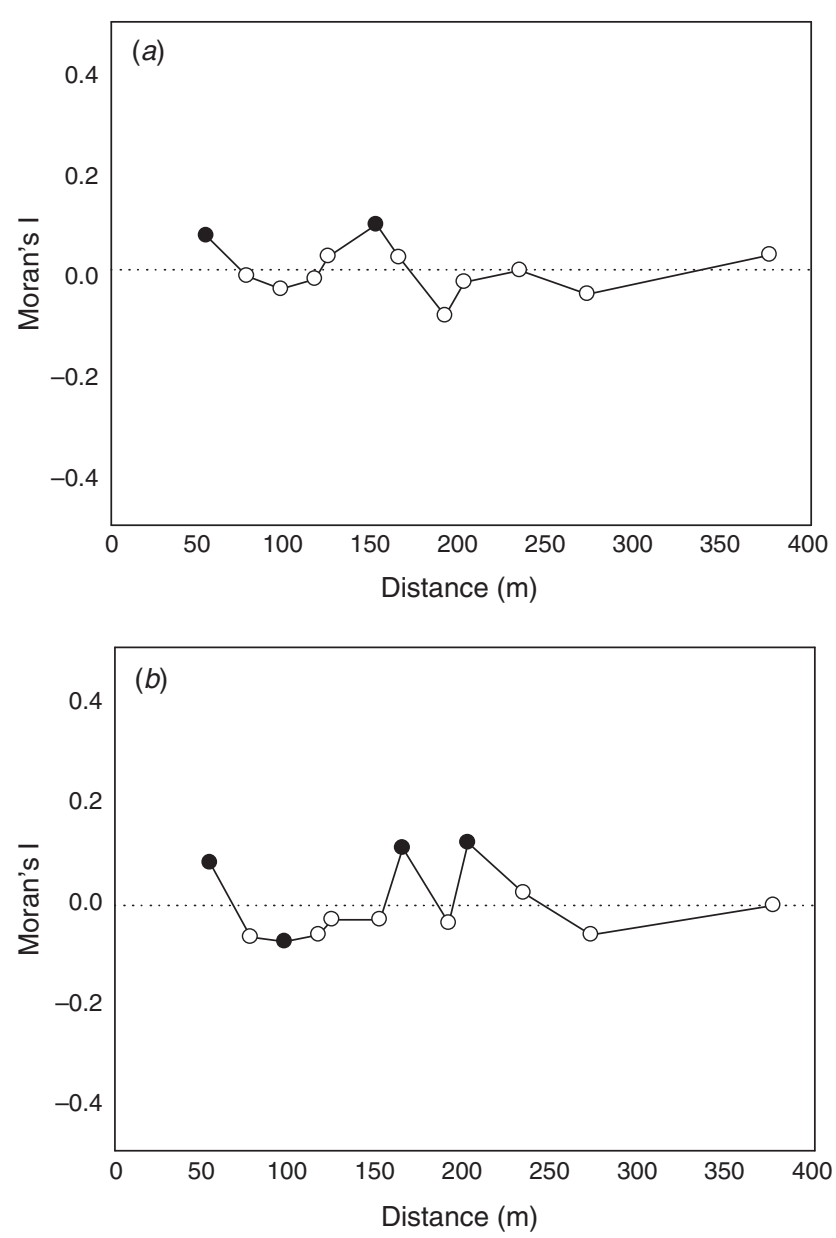

Fig. 1. Moran's I correlograms for (a) White-fronted Woodpecker (Melanerpes cactorum) and (b) Glittering-bellied Emerald (Chlorostilbon aureoventris). Black circles show distance classes statistically significant at $P<0.05$.

\section{Sap consumption by Glittering-bellied Emeralds}

The Glittering-bellied Emeralds foraged mostly on sap ( $83 \%$ of 54 observations), with; the remaining observations being consumption of nectar (14\%) and insects (3\%). The abundance of the Emeralds was positively associated with the abundance of White-fronted Woodpeckers $\left(R^{2}=0.46, P<0.001\right)$.

The abundance of Glittering-bellied Emeralds showed three positive autocorrelations: one at short distances (mean distance of $54.3 \mathrm{~m}$ ) and two at intermediate distances (mean distances of $164.5 \mathrm{~m}$ and $201.8 \mathrm{~m}$ ); and one negative autocorrelation (mean distance of $97.0 \mathrm{~m}$ ) (Fig. 1b), indicating a patchy or aggregated distribution. PCNM showed that 7 of the 52 spatial vectors were significantly associated with abundance of Glittering-bellied Emeralds, together accounting for $35 \%$ of variability in abundance (multiple regression, $R^{2}=0.35, P<0.001$ ). The correlation of the abundance values expected for the Glittering-bellied Emerald with the abundance of White-fronted Woodpecker accounted for $11 \%$ of the distribution $\left(R^{2}=0.11, P=0.01\right)$.

\section{Discussion}

Sap is an important component in the diet of White-fronted Woodpeckers and Glittering-bellied Emeralds during the dry season in the semiarid woodlands of Argentina. However, the spatial match between the abundance of the consumers and sap availability was species-specific. Our study suggests that processes related to sap consumption differ strongly between these two sap-eating species. The abundance of White-fronted Woodpeckers was not spatially correlated with the abundance of tree species used for sap consumption. For Woodpeckers, sap is an abundant resource and its availability and exploitation are more related to the social behaviour of territorial groups than to resource abundance. In contrast, the abundance of Glitteringbellied Emeralds was spatially structured in response to sap availability. This consumer-resource spatial relationship may be a result of spatial structuring of sap availability itself, in turn generated by regular spacing of the territories of White-fronted Woodpeckers.

At the local scale, neither abundance of tree species from which sap was obtained nor abundance of the most consumed species (P. ruscifolia) determined the pattern of use of territories by White-fronted Woodpeckers. This absence of spatial adjustment between the Woodpeckers and their sap trees at the local scale highlights other important aspects of the ecology of the species. On the one hand, the absence of resource tracking might result from a concentration of territorial groups, along with dense territorial packing in the area, which poses serious limitations on the movements of Woodpeckers in search of resources. On the other hand, a group territory might not be the appropriate scale to estimate availability of sap. Most sap consumption by each territorial group was concentrated at a single tree where the Woodpeckers actively maintained sap flows in the holes and drilled new ones. Thus, the availability of sap could be related more to single trees more than to all exploitable trees in a group territory.

We have shown that the hummingbirds are able to track sap resources successfully within the territories of the Woodpeckers. Tracking is a suitable foraging strategy for food resources that undergo predictable changes in spatial abundance over time. Glittering-bellied Emeralds are likely to be using sap as a replacement for nectar during periods of acute shortage of flowers, as they are equivalent resource in terms of energy and nutritional characteristics. Food scarcity is typical during the cold 
dry season (May-September) in the semiarid Chaco (Codesido and Bilenca 2004). During the study period, only two species of flower (Capparis salicifolia, Tillandsia sp.) were available to hummingbirds, which consumed their nectar. However, the Glittering-bellied Emerald does not consume sap during the flowering period of most plant species, in late spring.

Our findings raise interesting questions for further research on foraging and spatial distribution, which may be deeply influenced by the use of social information (Galef and Giraldeau 2001; Seppänen et al. 2007). Resource tracking may be facilitated by the activity of other species consuming the same resource, through tracking cues or signals (Saracco et al. 2004). The activity of sap consumption by White-fronted Woodpeckers is likely to provide a signal to Glittering-bellied Emeralds, facilitating both the resource and its spatial location in the forest.

In conclusion, the analysis of spatial patterns was a useful approach to explore the mechanisms that determine avian decisions related to sap consumption and how these processes interact between different species affecting their use of space. We found a strong difference between two species of sap-feeder in the scale of their spatial coupling with sap availability. This species-specific response is closely related to the ecology and life history of the two species. Future research should explore the spatial patterns of sap exploitation by facultative nectar consumers, such as orioles (Icteridae), which are the main nectar consumers of several plant species in the Neotropical region (Toledo and Hernández 1979; Ragusa-Netto 2002).

\section{Acknowledgements}

We appreciate the field assistance provided by Patricia Zelaya. Early versions of the manuscript have benefited from comments received during the meetings of members of the Laboratorio de Ecología de Aves at the Instituto de Ecología Regional, and from comments of two anonymous reviewers.

\section{References}

Blendinger, P. G. (1999). Facilitation of sap-feeding birds by the Whitefronted Woodpecker (Melanerpes cactorum) in the Monte desert, Argentina. Condor 101, 402-407. doi:10.2307/1370005

Borcard, D., and Legendre, P. (2002). All-scale spatial analysis of ecological data by means of principal coordinates of neighbour matrices. Ecological Modelling 153, 51-68. doi:10.1016/S0304-3800(01)00501-4

Borcard, D., Legendre, P., Jacquet, C. A., and Tuomisto, H. (2004). Dissecting the spatial structure of ecological data at multiple scales. Ecology $\mathbf{8 5}$, 1826-1832. doi:10.1890/03-3111

Cabrera, A. L., and Willink, A. (1980). 'Biogeografía de América Latina.' Serie de Biología 13. (Secretaría General de la Organización de los Estados Americanos: Washington, DC.)

Chapman, A., Bradford, M. G., and Hoskin, C. J. (1999). Sap suckers: a novel bird guild in wet sclerophyll forest of tropical north Queensland. Emu 99, 69-72. doi:10.1071/MU99009A

Codesido, M., and Bilenca, D. (2004). Variación estacional de un ensamble de aves en un bosque subtropical semiárido del Chaco argentino. Biotropica 36, 544-554.

Eberhardt, L. S. (2000). Use and selection of sap trees by Yellow-bellied Sapsuckers. Auk 117, 41-51. doi:10.1642/0004-8038(2000)117[0041: UASOST]2.0.CO;2

Fortin, M. J., and Dale, M. B. (2005). 'Spatial Analysis: A Guide for Ecologists.' (Cambridge University Press: Cambridge, UK.)

Galef, B. G., and Giraldeau, L. A. (2001). Social influences on foraging in vertebrates: causal mechanisms and adaptive functions. Animal Behaviour 61, 3-15. doi:10.1006/anbe.2000.1557
García, D., Chacoff, N. P., Herrera, J. M., and Amico, G. C. (2009). La escala espacial de las interacciones planta-animal. In 'Ecología y evolución de interacciones planta-animal: conceptos y aplicaciones'. (Eds R. Medel, M. A. Aizen and R. Zamora.) pp. 133-156. (Editorial Universitaria: Santiago, Chile.)

Genise, J. F., Straneck, R. J., and Hazeldine, P. (1993). Sapsucking in the White-fronted Woodpecker Melanerpes cactorum. Ornitologia Neotropical 4, 77-82.

Kattan, G. (1988). Food habits and social organization of Acorn Woodpeckers in Colombia. Condor 90, 100-106. doi:10.2307/1368438

Kozma, J. M. (2010). Characteristics of trees used by White-headed Woodpeckers for sap feeding in Washington. Northwestern Naturalist (Olympia, Wash.) 91, 81-86. doi:10.1898/NWN08-53.1

Legendre, P., and Legendre, L. (1998). 'Developments in Environmental Ecology. Numerical Ecology. Vol. 20.' (Elsevier Science: Amsterdam, the Netherlands.)

Miller, R. S., and Nero, R. W. (1983). Hummingbird-sapsucker associations in northern climates. Canadian Journal of Zoology 61, 1540-1546. doi:10.1139/z83-207

Morello, J., and Adámoli, J. (1968). 'Las Grandes Unidades de Vegetación y Ambiente del Chaco Argentino.' (INTA: Capital Federal, Buenos Aires, Argentina.)

Nekola, J. C., and White, P. S. (1999). The distance decay of similarity in biogeography and ecology. Journal of Biogeography 26, 867-878. doi:10.1046/j.1365-2699.1999.00305.x

Perry, J. N., and Dixon, P. M. (2002). A new method to measure spatial association for ecological count data. Ecoscience 9, 133-141.

Ragusa-Netto, J. (2002). Exploitation of Erythrina dominguezii Hassl. (Fabaceae) nectar by perching birds in a dry forest in western Brazil. Brazilian Journal of Biology 62, 877-883. doi:10.1590/S1519-6984200 2000500018

Rangel, T. F., Diniz-Filho, J. A. F., and Bini, L. M. (2006). Towards an integrated computational tool for spatial analysis in macroecology and biogeography. Global Ecology and Biogeography 15, 321-327. doi:10.1111/j.1466-822X.2006.00237.x

Saracco, J. F., Collazo, J. A., and Groom, M. J. (2004). How do frugivores track resources? Insights from spatial analyses of bird foraging in a tropical forest. Oecologia 139, 235-245. doi:10.1007/s00442-004-1493-7

Schlatter, R. P., and Vergara, P. (2005). Magellanic Woodpecker (Campephilus magellanicus) sap feeding and its role in the Tierra del Fuego forest bird assemblage. Journal für Ornithologie 146, 188-190. doi:10.1007/ s10336-004-0069-y

Seppänen, J. T., Forsman, J. T., Mönkkönen, M., and Thomson, R. L. (2007). Social information use is a process across time, space, and ecology, reaching heterospecifics. Ecology 88, 1622-1633. doi:10.1890/06-1757.1

Shochat, E., Abramsky, Z., Pinshow, B., and Whitehouse, M. E. A. (2002). Density-dependent habitat selection in migratory passerines during stopover: what causes the deviation from IFD? Evolutionary Ecology 16, 469-488. doi:10.1023/A:1020851801732

Southwick, E. E., and Southwick, A. K. (1980). Energetics of feeding on tree sap by Ruby-throated Hummingbirds in Michigan. American Midland Naturalist 104, 328-334. doi:10.2307/2424873

Tate, J. Jr (1973). Methods and annual sequence of foraging by the Sapsucker. Auk 90, 840-856.

Toledo, V. M., and Hernández, H. M. (1979). Erythrina oliviae: a new case of oriole pollination in Mexico. Annals of the Missouri Botanical Garden 66, 503-511. doi:10.2307/2398842

Wagner, H., and Fortin, M. J. (2005). Spatial analysis of landscapes: concepts and statistics. Ecology 86, 1975-1987. doi:10.1890/04-0914

Manuscript received 31 May 2010, accepted 15 November 2010 